\title{
The Impact of Interest Rate on Bank Deposit: Evidence from the Nigerian Banking Sector
}

Paul Ojeaga PhD

\author{
Department of Economics, Bergamo University, Bergamo, Italy
}

Omosefe Odejimi PhD

Department of Economics, Benin, Nigeria

Doi:10.5901/mjss.2014.v5n16p232

\begin{abstract}
The study investigates the effect of interest rates on customer savings behavior in the Nigerian banking sector, after identifying a host of factors that are likely to influence customer confidence in commercial banks such as average income, commercial lending, legal rights strength, central bank monetary policy and total annual commercial bank losses, using quantile regression estimation method, a non parametric estimation process that is based on the premise that the sample median will tend to that of the distribution and addresses issues of heteroscedastic errors and data stringency associated with the data used in the study under question. We find that interest rates were probably increasing bank deposits while income was also found to affect bank deposits in general.
\end{abstract}

Keywords: Interest rates, bank deposits, income, bank losses and monetary policy

\section{Introduction}

The dynamics between interest rate and customer savings behavior has not been overly researched. While the topic has generated a lot of discussions, no conclusive agreement has been reached as to the nature of how interest rates is likely to affect customer savings behavior particularly in the Nigerian context, furthermore even if many studies have investigated the role of interest rate on savings within the growth and financial business cycle context few have tried to address customers savings concerns as a matter of primary interest using a non parametric estimation technique as we do in this study.

A host of factors are likely to affect customer saving behavior in banks, some include the fixed saving interest rates which is likely to affect customers incentive to save, country specific wage rates which will depict the average allowance available after the individual budget demands, aggregate average annual bank losses which is likely to affect customer perception of how well banks are doing, institutional and regulatory strength which depicts the level of oversight function and internal control effectiveness, average bank lending, and country specific monetary policy as exerted by the country's apex financial agency such as the Central Bank.

Fixed savings account interest rates can also have strong consequences on overall average bank deposit and in most cases it is also affected by bank specific lending interest rates since it is customer deposits that are lent to private sector business with the expectations of returns on borrowed capital, making nominal interest rates to have a back-effect on fixed savings interest rates. Nominal interest rates therefore is likely to have an indirect causal effect on customer savings through fixed savings account interest rates which will probably be true since interest on savings are likely to be paid from returns on borrowed capital obtained from nominal interest on borrowed capital.

Low interest rates has been known to drive output production in many developed economies, as it creates enabling environment for private business expansion through the provision of easy access to capital for further production purposes. In December 2013 the United States all share index continued to soar amidst the Fed report to maintain interest rates at an all time low following the withdrawal of the stimulus finally signaling an end to the US financial crises. While nominal interest rate depicts the riskiness of the business environment it can also be used as a tool by a country's federal regulating agency in time of crisis for financial stabilization and quantitative easing of the economy.

The study investigates the impact of interest rates on bank deposits in Nigeria, using quantile regression estimation a non parametric estimation method that is based on the premise that the sample median will tend to that of the distribution and produces consistent estimates in the presence of heteroscedastic errors and outliers in the response measurement, The rest of the paper is divided into scope and objectives of study, review of literature, stylized facts on 
interest rates and bank deposits, theory and methodology, empirical analysis and results, discussion of results and the concluding sections.

\section{Scope and Objectives}

The paper presents empirical evidence of the factors that affect customer's savings behavior (measured as aggregate bank deposit in the study) in the Nigerian banking industry by reviewing the effects of interest rates on bank deposits in Nigeria. The objectives of the study include:

a.) To examine the extent to which interest rate affects customer bank saving (bank deposits) in the Nigeria banking sector.

b.) To determine the extent to which average wage rates affects aggregate bank deposits in the Nigeria banking sector since customer excess allocation is likely to positively drive up savings

c.) To examine the effect of institutional factors and bank internal controls on customers savings perception in the Nigerian banking sector.

d.) To determine the effect of the CBN monetary policy on bank deposits in general in the Nigerian banking sector.

\section{Review of Literature}

The review of past and current literature is carried out in this section. Past studies have investigated the effect of nominal interest rates on growth. Bernake and Gertler (1995) state that the credit channel is characterized by two channels which are the balance sheet channel and the bank lending channel, this was probably true since access to credit will depend on current balance and report of credit committees.

Nominal interest rate is also fixed by a country apex bank and has the capacity to affect bank deposit making bank cost of funds to increase with country specific monetary policy Bernanke and Blinder (1988), Kashyap and Stein (1994, 2000) and Walsh (2003).

Others also make a case for portfolio substitution arguing that policy stringency is likely to drive up cost of credit access and have a negative effect on deposit yields forcing household to economize Kishan and Opiela (2000) Ehrmann et al (2001). They argue extensively that a nation's Central Bank policy is likely to have strong consequences of bank deposits forcing banks to channel financing away from cheap deposits to more expensive liabilities.

The study by Martinez Peria and Schmukler (2000) analyzed the relationship between perceived bank risk and interest rate for Latin America while Ellis and Flannery (1992), Brewer and Monschean (1994) and Keeley (1990) analyzed the same effect for the United States and finds that there exist a relationship between interest rates and perceived bank risk.

The study by Galac and Kraft (2000) investigates deposit interest rates for the US and find that foreign bank were found to offer lower deposit interest rates than domestic banks, this negative interest rate elasticity shows larger differentials for foreign banks in times of crisis compared to domestic banks.

This study investigates the impact of interest rates on bank deposit in Nigeria, the findings can have strong implication for the apex Bank monetary policy as well as provide useful incites for many commercial banks. For how interest rates affect bank deposits see the study by Walsh (2003) for further discussion.

\section{Stylized Facts on Interest Rates and Bank Deposit}

In this section we present stylized facts on the study under question. Average bank deposits is continually on the increase in Nigeria see Fig. 1 below, this can be attributed to sustained customer excess revenue allocation after taking care of their yearly budgetary expenditure concerns. Sustained growth particularly in global commodity prices and the reintroduction of democratic rule since 1999 has meant that workers have been able to agitate through dialogue adjustment to wage rates to meet with current inflation trends in the Nigerian economy.

The riskiness of the Nigerian business environment despite an annual average growth of approximately 7.4 percent in the past 4 years is still a matter of concern for the Central Bank of Nigeria the apex monetary regulatory agency in Nigeria. Fig. 2 below shows that since the major Nigerian banking reforms of 2009/2010 average interest rates have skyrocketed to over 10\% depicting the riskiness in the Nigeria business environment. The riskiness of the business environment is likely to have a back effect of depositor's perception of the Nigerian commercial bank ability to maintain stable banking environment this is likely to affect overall liquidity of banks. The expected relationship between interest 
rates and depositors perception will be one in which interest rates will have a positive effect on deposits if the business environment becomes relatively stable.

Fig. 1

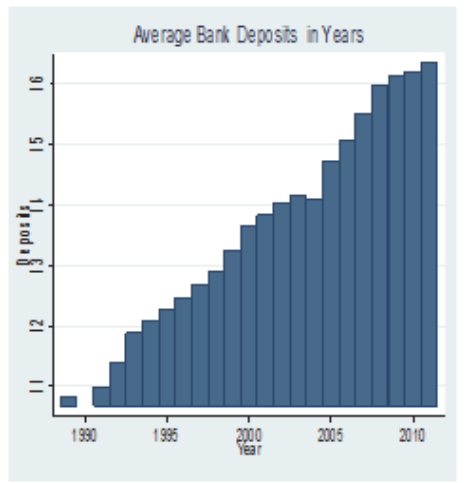

Fig.2

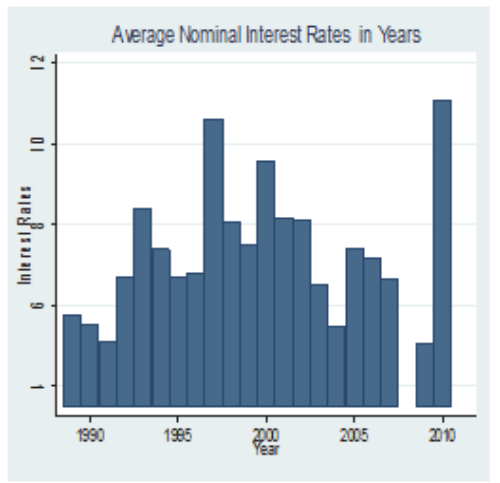

Aggregate income is also on the increase see fig3 this is particularly noticeable from the early 2000 s, legal rights strength which we use as a measure of oversight function is also on the decrease meaning that regulatory agencies effectiveness in checking irregular activities in the Nigerian banking sector is not likely to be yielding sufficient results to boost customer perceptions regarding the integrity of the management of Nigerian banks.

The drastic reduction in the oversight functions see fig. 4 also depicts judiary strength in effectively prosecuting bank officials accused of fraud and other miscoduct. The 2010 commercial bank management crises also brings to fore these existing weaknesses since the judiciary has till date not be able to arrive at conclusive verdicts of the indicted bank management staffs concerned, the intervention by government and political officials also remains a constant reminder of the weakness of the judiciary and regulatory agencies in effectively checking banking irregularities in the banking sector.
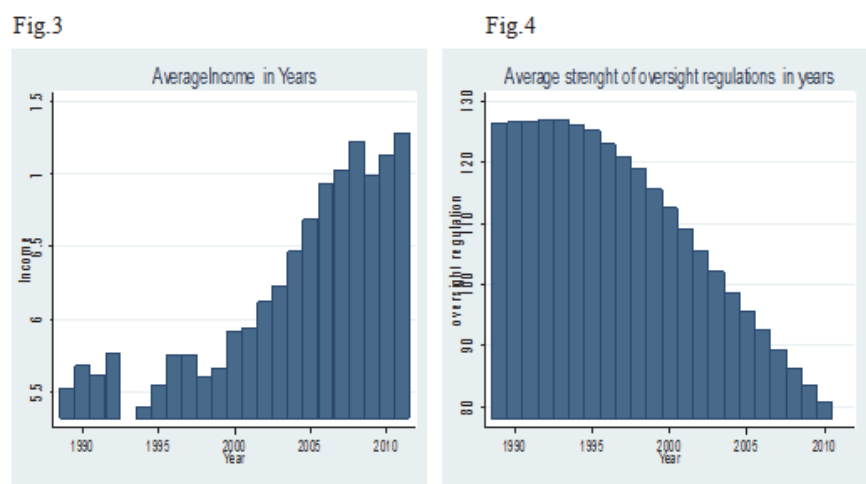

Commercial lending is also at an all time low and has not returned to the pre 1990s levels see fig.5 showing that commercial banks were not lending to the private sector in a significant manner that can drive output production in the real sector. This was probably due to the riskiness of the Nigerian business environment that was probably driving interest rates up and making borrowers to be averse to borrowing because of the high tendency of likely default fears. The stringency of the borrowing process by banks on borrowers was also an issue as this was also probably discouraging private individuals and businesses from lending.

Banks were also recording high amount of losses see fig. 6 this can be attributed to mismanagement in banks and high fraud occurrences particularly management fraud been perpetuated on a large scale in the Nigerian banking sector, once again confirming the assertion that over sight functions were probably at an all time low, or that regulatory agencies official were probably corroborating with bank officials in allowing for lapses in the regulatory measures enforcement process in the Nigerian banking sector. 
Fig. 5

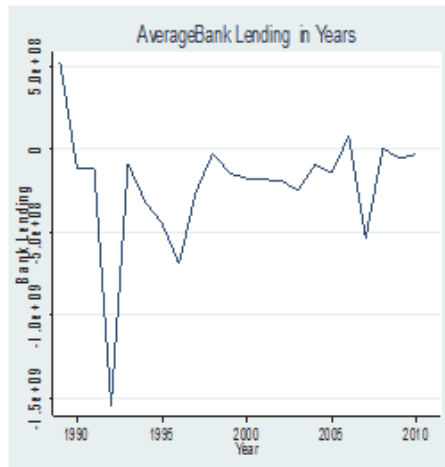

Fig.6

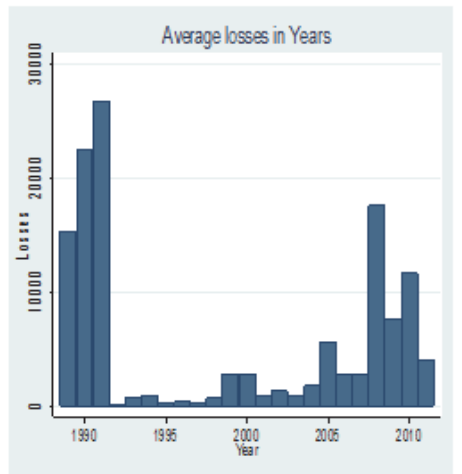

\section{Theory and Methodology}

Past theory Kraft and Galac (2007), have estimated the impact of savings deposit interest rates on bank failures using OLS and system GMM and find that fixed saving deposit interest rate has a strong effect on bank failure since they depict the riskiness of the business environment.

Theory we rely on is one in which interest rates will affect deposit indirectly through the following propositions.

a.) Interest rate is likely to drive up the cost of accessing capital in commercial banks which could reduce lending by borrowers who will be averse to accessing such capital due to the high tendency to default

b.) Poor commercial bank lending is likely to affect customer fixed savings deposit interest rates, affecting depositor's perception of commercial banks.

c.) Finally poor perception of commercial banks by depositors is likely to lead to alternative methods of savings by depositors such as investment in shares and other discount houses who will be likely to offer higher interest rates on depositor's capital.

The method of identification used in this paper is one in which interest rate is put in the bank deposit model, we look at a list of variables that are likely to affect customer perception of Nigerian commercial banks such as commercial banks annual losses, average wage rates (income) in Nigeria, legal right strength the measure of oversight regulation strength, money supply a measure of Central Bank monetary policy and average commercial bank losses which captures management lapses, fraud occurrence rates and average commercial bank performance in Nigeria. This notion is supported by Bernanke (2003) and Borio and Zhu (2007) who state that interest rates and monetary policy will depict investors risk perception of the business environment.

Bank deposits will now be expressed as a function of $f$ (interest rates, losses, income, legal right strength, bank lending ). The model to be estimated can now be written below in equation 1 , where deposit will depend on interest rates and the list of exogenous variables and the error term.

(1.) Deposits $_{t}=\alpha_{0}+\alpha_{1}$ Interest rates $_{t-1}+\alpha_{2} X_{t-1}+\epsilon_{t}$

Where $\alpha_{0}$ is a constant, $X_{t}$ is the vector of exogenous variables and $\epsilon_{t}$ is the error term. The variable year is included in the model to account for annual differences in interest rates fluctuations that can affect deposits. The method of estimation used as stated earlier is the quantile regression estimation method a non-parametric estimation technique, which produces robust results in the presence of heterscedasticity and outliers in the response measurement allowing us to argue that our model is not likely to suffer from misspecification due to the noisiness of the deposit variable.

\section{Data and Sources}

Times series data is used in this study, all data are obtained from Central Bank of Nigeria data set and World Development Indicators of the World Bank data unless otherwise stated for the period of 1989 to 2012 a period of twenty three years. Table 1 below also shows the descriptive statistics of all data used in the study. 
Table 1: Descriptive Statistics

\begin{tabular}{lccccc}
\hline Variable & Observations & Mean & Std. Dev. & Min & Max \\
\hline Deposits & 23 & 2661476 & 3907756 & 43411.4 & 1.2300000 \\
Bank losses & 23 & 5665.766 & 7697.071 & 73.11 & 26678.6 \\
Income & 23 & 585.9815 & 415.6299 & 203.4922 & 1452.095 \\
Strength of Legal Rights & 23 & 108.5478 & 17.25143 & 78 & 127 \\
Bank Lending & 22 & -2.20000000 & 3.7700000 & -1.5000000000 & 5.2100000 \\
Interest Rates & 22 & 7.149727 & 1.802656 & 3.509 & 11.06417 \\
Money Supply & 23 & 2.654803 & 2.203954 & .6479998 & 8.518194 \\
\hline
\end{tabular}

Note: The descriptive statistics are obtained from the summary statistics of variables used in the study

Deposit is the aggregate sum of all yearly customer deposit in Naira in banks obtained from CBN data, nominal interest rates is the average commercial bank lending rate interest in percentages, bank losses are declared losses by banks in Naira obtained from CBN data, FDI is the inflow of all foreign investment to the private sector of the Nigerian economy in constant USD, income is the average GDP per capita in USD, strength legal strength is a measure of judicial effectiveness using score data obtained from the world bank, bank lending is aggregate commercial bank lending to the private sector in constant USD and money supply is the aggregate money in circulation in constant USD.

\section{Empirical Analysis and Results}

In this section we argue in a critical manner why it should be believed that nominal interest rates have a high tendency to affect customer saving behavior. In this case we state that due to the nature of the relationship between interest rates and bank deposits that interest will have an indirect causative effect on customer savings (deposit) that will be positive in nature since returns from commercial banking activities such as borrowing to the private sector of the economy will be used by banks in paying of fixed savings accounts interest rates. This allows us to justify the reasons for the investigation of the impact of interest rates on bank deposits as the measure of customer's savings in the Nigerian banking sector.

\subsection{Results}

We present the results of the regression of interest rates on deposits below in table 2 . The results of the simultaneous quantile regression and the bootstrapped simultaneous quantile regressions show that interest rates were not having a significant effect on deposits. The stringency of the data set used in the study was probably affecting the results obtained from the first two regression carried out where we try to check for the robustness of the predictive power of the datasets see columns 1 and 2 in table 2.

The results of the quantile regression and quantile regression (qreg2) wrapper developed by Machando and Silva (2013) where we controlled for heteroscedastic errors due to the noisy nature of the deposit variable show that interest rates were having a positive effect on customer savings (average annual bank deposits) in the Nigerian banking sector see columns 3 and 4 in table 2.

Income was also affecting customer's savings (bank deposits) although the effect income was exerting on customer savings was weak see column 4 table 2. It depicted that the assertion that increases in wage rates were probably driving up bank deposits since depositors were probably saving up excess their excess revenue allocation after addressing their individual budgetary concerns.

Other factors such as bank lending see column 3 table 2 was exerting a negative effect on bank deposits since lending as stated earlier were at an all time low and lending was probably not profitable for commercial banks due to the risky nature of the Nigerian business environment. This result was not the same after controlling for the noisy nature of deposits see column 4 table.

Money supply also exerted a strong effect on customer savings see column 3 table 2, showing that the Central Bank's policy of bank consolidation were probably driving up investors confidence in the banking sector. This result was also not the same after controlling for heteroscedastic errors using the qreg2 wrapper in column 4 table 2. 
Table 2: Impact of Interest rate in customer deposits

\begin{tabular}{|c|c|c|c|c|}
\hline Variables & $\begin{array}{c}\text { (1) } \\
\text { deposit }\end{array}$ & $\begin{array}{c}\text { (2) } \\
\text { Deposit }\end{array}$ & $\begin{array}{c}\text { (3) } \\
\text { deposit }\end{array}$ & $\begin{array}{c}\text { (4) } \\
\text { deposit }\end{array}$ \\
\hline Interest rate & $\begin{array}{c}391.301 \\
(435.772)\end{array}$ & $\begin{array}{c}391.301 \\
(419.727)\end{array}$ & $\begin{array}{c}856.419^{\star \star \star} \\
(114.612)\end{array}$ & $\begin{array}{c}391.301^{* * *} \\
(127.656)\end{array}$ \\
\hline Income & $\begin{array}{c}6.821 \\
(6.203)\end{array}$ & $\begin{array}{l}6.821 \\
(4.351)\end{array}$ & $\begin{array}{l}-1.276 \\
(3.460)\end{array}$ & $\begin{array}{l}6.821^{*} \\
(3.677)\end{array}$ \\
\hline Legal rights strength & $\begin{array}{c}-65.831 \\
(154.41)\end{array}$ & $\begin{array}{l}-65.831 \\
(140.57)\end{array}$ & $\begin{array}{l}114.16^{\star * *} \\
(137.454)\end{array}$ & $\begin{array}{l}-65.831 \\
(91.742)\end{array}$ \\
\hline Bank lending & $\begin{array}{c}0.000308 \\
(0.0033)\end{array}$ & $\begin{array}{l}0.000308 \\
(0.00135)\end{array}$ & $\begin{array}{c}-0.0075^{\star \star \star} \\
(0.00084)\end{array}$ & $\begin{array}{l}0.000308 \\
(0.00065)\end{array}$ \\
\hline Losses & $\begin{array}{l}97.64 \\
(115)\end{array}$ & $\begin{array}{c}97.64 \\
(151.4)\end{array}$ & $\begin{array}{l}1.110^{* * *} \\
(79.21)\end{array}$ & $\begin{array}{l}97.64 \\
(62.3)\end{array}$ \\
\hline Money supply & $\begin{array}{c}452.839 \\
(342.759)\end{array}$ & $\begin{array}{c}452.839 \\
(448.272)\end{array}$ & $\begin{array}{c}1262.06^{\star \star \star} \\
(197.042)\end{array}$ & $\begin{array}{c}452.839 \\
(290.829)\end{array}$ \\
\hline Year effect & No & No & Yes & No \\
\hline $\begin{array}{l}\text { Observations } \\
\text { R-squared }\end{array}$ & 22 & 22 & 22 & $\begin{array}{c}22 \\
0901\end{array}$ \\
\hline
\end{tabular}

Standard errors in parentheses

${ }^{\star * *} p<0.01,{ }^{* *} p<0.05,{ }^{*} p<0.1$

\section{Discussion of Results}

Interestingly the results have strong implications for customer's savings and stake holders in Nigerian banking sector particularly shareholders, management staff and banking regulatory authorities.

Nominal interest rates were having strong positive effects on deposits and were probably affecting customers savings in a significant manner, this was probably true since interest rates were at an all time low before the 2007 financial crisis and counter measures taken by the Central Bank of Nigeria regarding bank consolidation as well as sustained commodities prices driven growth in Nigeria despite the global recession has sustained high customers savings perception in the Nigeria banking system.

Income was also having significant effects on savings since excess revenue allocation were available to be saved which was driving up customers deposits in commercial banks in Nigeria. This was however not commensurate with commercial bank lending. The riskiness of the Nigeria business environment was still an issue, this needs to be addressed by putting in place sufficient cushions that could reduce the transaction cost of doing business through the development of basic socio infrastructure that could improve business transaction profitability as well reducing the cost of access to capital since the cost of capital itself was probably making borrowers to be averse to borrowing for further production purposes since this will reduce profits and increase the likelihood to default.

The predictive power of the dataset used in this study was also investigated while quantile regression estimation is suitable for small sample analysis the results of the boostrapped simultaneous quantile regression show that interest rates are not exerting a significant effect on deposits, we present these results even though we disregard the effect of this predictive check on the outcome of our findings since the qreg2 wrapper controls for heteroscedastic errors in the response measurement of our datasets and the presence of outliers making us to have some confidence in the greg2 estimation results see Machando and Silva (2013) for further discussions. All the objectives of the study are realized and the outcomes of the objectives are listed below as follows;

a.) Interest rate were affecting customer bank saving (bank deposits) in the Nigeria banking sector in a positive manner and driving up saving deposits in banks.

b.) Average wage rates were affecting aggregate bank deposits in the Nigeria banking sector positively it was likely that customer excess budgetary allocation were driving up savings in Nigerian commercial banks

c.) Institutional factors such as central bank oversight activities and other internal bank controls and bank internal controls (measure using the legal rights strength index) were having no effect on customer's savings perception in the Nigerian banking sector since the preferred results using the qreg2 wrapper depict no effect on institutions on deposits see column 4 table 2.

d.) CBN monetary policy were having no effect on bank deposits in general in the Nigerian banking sector see the results in column 4 table 2 where. 


\section{Conclusions}

In the concluding sections we discuss the policy implications of the effect of average annual nominal interest rates on commercial bank deposits in Nigeria. The results obtained show that bank oversight functions were currently exerting a weak effect on deposits. Also deposits were probably driven not only by current interest rates but also by the sustained growth in the Nigeria economy that have allowed for the upward review of wage rates, which was attributed to be responsible for the availability of excess budget allocation to workers which were probably been saved up in commercial banks.

Bank lending was found not to be commensurate with the current level of savings and banks were probably failing in their primary obligation which is lending to private sector business and individuals. It was also discovered that CBN monetary policy (measured using money) were probably not effectively driving deposits despite its recent consolidation efforts, since the impact of money supply on bank deposits were not robust and exerting no significant effect on savings see column 3 and 4 table two.

The policy implication of the findings is that oversights regulations have to be strengthened, while inflation has to be checked to keep wages above basic individual budgetary demands as it stands currently. Other issues such as bank lending have to be encouraged by reducing nominal interest rates and improving the business environment by developing infrastructure to reduce the transaction cost of conducting business in the country, this is likely to make the business environment less risky and encourage private sector business to be less averse to borrowing from commercial banks since less riskier business environment could mean less likelihood to default on bank loans.

Finally, bank consolidation such as mergers and other internal controls such as management probes, and other bank reforms should be followed up with strategies to boost customers confidence in banks through encouraging more transparency in the management of Nigeria commercial banks, as this can increase depositors confidence in banks allowing the Central Bank monetary policy to be used as a pointer by depositors to measure commercial banks management effectiveness in running banks, which can have strong effects on deposits.

\section{References}

Altubas, Y., Gambacorta, L., and Marquez, D. "Securitization and the Bank Lending Channel", Working Paper, European Central Bank, Frankfurt, 2007.

Bernanke, B. S. and Blinder, A. S. "The Federal Funds Rate and the Channels of Monetary Transmission." American Economic Review, 1992, 82(4), pp. 901-21.

Bernanke, B. S. and Gertler, M. "Agency Costs, Net Worth, and Business Fluctuations." American Economic Review, 1989, 79(1), pp. 14-31.

Diyatat, P. (2008), "Monetary policy implementation: Misconceptions and their consequences", BIS Working Papers No. 269.

Galac T. and Kraft E. (2003) "Monetary and Financial Policies for "de-euroization" - a Case Study of Recent Croatian Experience" Croatian Niational Bank Publication

Jiménez, Gabriel, Ongena, Steven, Peydró, José-Luis and Saurina, Jesús. (2008). "Hazardous Times for Monetary Policy: What Do Twenty-Three Million Bank Loans Say About the Effects of Monetary Policy on Credit Risk?," Madrid: Banco de España.

Kashyap, Anil K, and Jeremy C. Stein, 1994, "Monetary policy and bank lending", in N. Gregory Mankiw, ed.: Monetary Policy (University of Chicago Press, Chicago, IL).

Kashyap, Anil K, and Jeremy C. Stein, 2000, "What do a million observations on banks say about the transmission of monetary policy?" American Economic Review 90, 407-428.

Machando and Silva (2013) "Quantile Regression and Heteroscedasticity" University of Essex Working Paper.

Walsh (2003) "Monetary Theory and Policy" MIT Press Canbridge Massachussetts United States. 